\title{
KAJIAN PENAMBAHAN PAPER SULDGE YANG BERVARIASI TERHADAP SIFAT FISIK DAN MEKANIK CEILING BRICK
}

\author{
M. Abdul Aziz Kurniawan \\ Eko Suwarno, Boedya Djatmika
}

\begin{abstract}
Abstrak:Ceiling brick buangan paper sludge salah satu alternatif membuat pelat lantai, secara ekonomis lebih murah dan memiliki kuat tekan setara dengan beton konvensional K300. Penelitian ini menggunakan metode eksperimen. Terdapat dua jenis benda uji yang digunakan yaitu berbentuk kubus dengan ukuran $5 \mathrm{~cm}$ x $5 \mathrm{~cm}$ x $5 \mathrm{~cm}$ untuk mengetahui kualitas bahan ceiling brick dan benda uji berbentuk produk ceiling brick untuk mengetahui kualitas produk ceiling brick. Variasi paper sludge yang digunakan adalah $2 \%, 4 \%, 6 \%$, dan $8 \%$. Satu benda uji dilakukan dua pengujian yaitu uji fisik (rembesan air) dan mekanik (kuat tekan). Metode penelitian menggunakan analisa statistik One Way dan dilanjutkan analisis Tukey. Hasil dari penelitian ini adalah (1) Kuat tekan produk ceiling brick dengan campuran paper sludge berurut-urut $0 \%, 2 \%$, $4 \%, 6 \%$, dan $8 \%$ sebesar 8.43 MPa, 9.39 MPa, 11.28 MPa, 10.31 MPa, dan 8.30 MPa. Nilai rata-rata rembesan air produk ceiling brick dengan variasi berurut-urut $0 \%, 2 \%, 4 \%, 6 \%$, dan $8 \%$, yaitu sebesar $0.35 \mathrm{ml} / \mathrm{menit}$, $0.37 \mathrm{ml} / \mathrm{menit}, 0.35 \mathrm{ml} / \mathrm{menit}, 0.42 \mathrm{ml} / \mathrm{menit}$, dan $0.36 \mathrm{ml} / \mathrm{menit}$. (2) Kuat tekan mortar kubus ceiling brick dengan campuran paper sludge berurut-urut $0 \%, 2 \%$, $4 \%, 6 \%$, dan 8\% sebesar 105.66 MPa, 112.67 MPa, 104.20 MPa, 98.55 MPa, dan 105.24 MPa. Rembesan air mortar kubus ceiling brick dengan variasi berurut-urut $0 \%, 2 \%, 4 \%, 6 \%$, dan $8 \%$, yaitu sebesar $0,59 \mathrm{ml} / \mathrm{menit}$, $0,54 \mathrm{ml} / \mathrm{menit}, 0,46 \mathrm{ml} / \mathrm{menit}, 0,27 \mathrm{ml} / \mathrm{menit}$, dan $0,28 \mathrm{ml} / \mathrm{menit}$. (3) Uji kuat tekan dan rembesan air terhadap produk ceiling brick yang telah dicampur paper sludge mengalami perbedaan tetapi tidak signifikan. (4) Uji kuat tekan terhadap mortar kubus ceiling brick yang dicampur paper sludge mengalami perbedaan tetapi tidak signifikan. Sedangkan uji rembesan air tehadap mortar kubus ceiling brick yang dicampur paper sludge mengalami perbedaan yang signifikan. (5) Campuran paper sludge 4\% pada produk ceiling brick dan campuran paper sludge $2 \%$ pada mortar kubus ceiling brick menghasilkan kuat tekan optimum.
\end{abstract}

Kata-kata kunci: paper sludge, limbah kertas, ceiling brick, sifat fisik \& mekanik

Abstract: Paper sludge ceiling bricks are an alternative to making floor plates, are economically cheaper and have compressive strength equivalent to conventional K300 concrete. This research is using experimental method. There are two types of specimens used which are cube shaped with a size of $5 \mathrm{~cm} \times 5 \mathrm{~cm} \times 5 \mathrm{~cm}$ to determine the quality of ceiling brick material and specimens in the form of ceiling brick products to determine the quality of ceiling brick products. Paper sludge variations used are 2\%, 4\%, 6\%, and 8\%. One test object was carried out two tests, namely physical test (water seepage) and mechanical (compressive strength). The research method uses One Way statistical analysis and Tukey analysis continues. The results of this study are (1) Compressive strength of brick brick products with a mixture of paper sludge in sequence of $0 \%, 2 \%, 4 \%, 6 \%$, and $8 \%$ at $8.43 \mathrm{MPa}, 9.39 \mathrm{MPa}, 11.28 \mathrm{MPa}$, $10.31 \mathrm{MPa}$ and 8.30 MPa. The average seepage value of ceiling brick products with sequential variations of $0 \%, 2 \%, 4 \%, 6 \%$, and $8 \%$, which is $0.35 \mathrm{ml} /$ minute, $0.37 \mathrm{ml} /$ minute, $0.35 \mathrm{ml}$ / minute, $0.42 \mathrm{ml} /$ minute minutes, and $0.36 \mathrm{ml} /$ minute. (2) Compressive strength of ceiling brick cube mortar with a mixture of paper sludge in a sequence of $0 \%, 2 \%, 4 \%, 6 \%$, and $8 \%$ by 105.66 MPa, 112.67 MPa, 104.20 MPa, 98.55 MPa and 105.24 MPa. Mortar cube ceiling water seepage with sequential variations of $0 \%, 2 \%, 4 \%, 6 \%$, and $8 \%$, in the amount of $0.59 \mathrm{ml} /$ minute, $0.54 \mathrm{ml} /$ minute, $0.46 \mathrm{ml} /$ minute, $0.27 \mathrm{ml} /$ minute, and $0.28 \mathrm{ml} / \mathrm{min}$ ute. (3) The compressive strength and water seepage tests on ceiling brick products that have been mixed with paper sludge experience differences but are not significant. (4) Compressive strength test of ceiling brick cube mortar mixed with paper sludge is different but not significant. While the water seepage test of ceiling brick cube mortar mixed with paper sludge experienced a significant difference. (5) 4\% paper sludge mixture in ceiling brick products and $2 \%$ paper sludge mixture in ceiling brick cube mortars produce optimum compressive strength.

Keywords: paper sludge, waste paper, ceiling brick, physical \& mechanical properties

M. Abdul Aziz Kurniawan adalah Alumni Jurusan Teknik Sipil Fakultas Teknik UM; E-mail: fazizkurniawan. fb@gmail.com; Eko Suwarno dan Boedya Djatmika adalah Dosen Jurusan Teknik Sipil Fakultas Teknik UM; Jalan Semarang No.5 Malang 65145; E-mail: eko.suwarno.ft@um.ac.id dan boedya.djatmika.ft@um.ac.id 


\section{PENDAHULUAN}

Indonesia merupakan salah satu produsen pulp dan kertas terkemuka di dunia, untuk industri pulp berada diperingkat ke-9 dan industri kertas diperingkat ke-6 dunia. Sedangkan di Asia Tenggara menempati peringkat pertama untuk industri pulp dan kertas (Kemenperin, 2016). Selama ini buangan paper sludge merupakan masalah yang besar bagi industri pulp dan kertas pada umumnya. Adanya paper sludge membuat perusahaan mengeluarkan biaya yang lebih untuk memasukkannya ke dalam landfill. Apabila keadaan ini dibiarkan terus-menerus, maka semakin lama pabrik akan kekurangan lahan untuk penimbunan limbah sehingga dimungkinkan terjadinya pencemaran lingkungan. Menurut Khusna (2012), adanya kandungan anorganik dalam paper sludge berpotensi untuk dimanfaatkan sebagai bahan bangunan, maka dalam hal ini sludge kertas dapat digunakan sebagai substitusi bahan baku untuk memenuhi kebutuhan masyarakat terhadap bahan bangunan yang semakin meningkat.

Menurut Irawan (2006), PT. Adiprima Suraprinta dari Jawa Pos Group yang berkedudukan di Legundi Gresik memproduksi kertas dari kertas bekas. Bahan baku diproses menjadi bubur kertas, selanjutnya dipilah, warna putih diproses sebagai kertas, sedangkan limbah berwarna abu-abu karena warna tinta dibuang. Jumlah limbah paper sludge atau bubur kertas yang dihasilkan kira-kira 250 ton/ hari. Dengan demikian diperlukan upaya untuk mengatasi permasalahan tersebut, salah satu alternatif adalah dengan memanfaatkannya menjadi bahan campuran ceiling brick atau dak keraton (keramik komposit beton), den- gan dasar kandungan anorganik yang cukup tinggi terutama $\mathrm{Ca} C \mathrm{CO} 3$ (Hastutik dkk, 2006).

Ceiling brick ini terbuat dari tanah liat (keramik) yang di buat dengan cara di extrude sehingga berbentuk menyerupai kubus dengan lubang-lubang dibagian tengahnya. Paper sludge juga memiliki kandungan yang sama dengan tanah liat yaitu $\mathrm{SiO} 2$ atau persenyawaan silica dan oksigen yang mempunyai titik lebur tinggi pada proses pembakaran dan menjadikan tanah keras dan kuat. Penelitian ini sangat perlu dilaksanakan untuk mengeksplorasi lebih lanjut tentang potensi limbah paper sludge menjadi bahan baku ceiling brick. Menurut Maghfironi (2011), keuntungan dalam ceiling brick yaitu memiliki bobot yang lebih ringan ( $\pm 130-150 \mathrm{~kg} / \mathrm{m} 2)$ dibandingkan dengan beton $( \pm 288 \mathrm{~kg} / \mathrm{m} 2)$. Sehingga bangunan yang menggunakan ceiling brick yang dicampur dengan paper sludge untuk pelat lantai, bangunan tersebut akan menerima beban lebih ringan lagi dibanding pelat lantai yang menggunakan beton walaupun kualitas antara beton dengan ceiling brick sama. Hal tersebut dilihat dari bahan dasar beton yang lebih banyak dibanding ceiling brick yang dicampur paper sludge. Sehingga dapat diketahui komposisi campuran paper sludge sebagai bahan baku ceiling brick dan dapat dimanfaatkan secara maksimal dalam aplikasinya sebagai pelat lantai.

Berdasarkan hal diatas, paper sludge mempunyai potensi untuk dimanfaatkan sebagai bahan campuran ceiling brick. Selain itu, penelitian ini juga untuk mengetahui kualitas bahan ceiling brick yang telah dicampur dengan paper sludge dan untuk mengetahui campuran paper sludge yang paling optimum sebagai bahan campuran ceiling brick. 


\section{METODE}

Metode penelitian yang digunakan dalam penelitian ini termasuk kategori penelitian eksperimen yaitu dengan melakukan pengujian sampel di Laboratorium Struktur Fakultas Teknik Universitas Negeri Malang. Sehingga hasil penelitian dapat dipertanggungjawabkan secara ilmiah. Dalam penelitian ini terdapat dua variabel yaitu variabel bebas dan variabel terikat. Dalam lingkup penelitian ini yang digunakan sebagai variabel bebas adalah kadar paper sludge sebesar $0 \%, 2 \%$, $4 \%, 6 \%$, dan $8 \%$ terhadap sifat fisik dan mekanik ceiling brick. Variabel terikatnya adalah kuat tekan yang dihasilkan dalam pengujian.

Data yang diperoleh dari penelitian ini adalah nilai kuat tekan, berat volume, dan rembesan air pada produk dan mortar kubus ceiling brick. Penentuan kadar paper sludge bertujuan untuk memperoleh campuran paper sledge yang optimum. Penelitian ini dilaksanakan di Laboratorium Bahan dan Laboratorium Struktur Jurusan Teknik Sipil Fakultas Teknik Universitas Negeri Malang. Dalam penelitian ini dilakukan beberapa tahapan kerja seperti yang tercantum pada Gambar 1 di bawah ini.

Dalam penelitian ini menggunakan dua jenis benda uji yaitu benda uji berbentuk produk ceiling brick bertujuan untuk mengetahui kualitas produk ceiling brick dan berbentuk mortar kubus ceiling brick dengan ukuran $5 \mathrm{~cm}$ x 5 $\mathrm{cm} \times 5 \mathrm{~cm}$ untuk mengetahui kualitas bahan ceiling brick. Kode benda uji produk ceiling brick yang telah dicampur paper sludge dengan variasi berurut-urut $0 \%, 2 \%, 4 \%, 6 \%$, dan 8\% yaitu DK0, DK2, DK4, DK6, dan DK8. Untuk kode benda uji mortar kubus ceiling brick yang telah dicampur paper sludge dengan variasi berurut-urut $0 \%, 2 \%, 4 \%, 6 \%$, dan 8\% yaitu MT0, MT2, MT4, MT6, dan MT8. Pengujian dalam penelitian ini yaitu uji sifat fisik dan mekanik pada ceiling brick. Sifat fisik dalam penelitian ini yaitu uji berat volume dan uji rembesan air. Sedangkan sifat mekanik dalam penelitian ini yaitu uji kuat tekan.

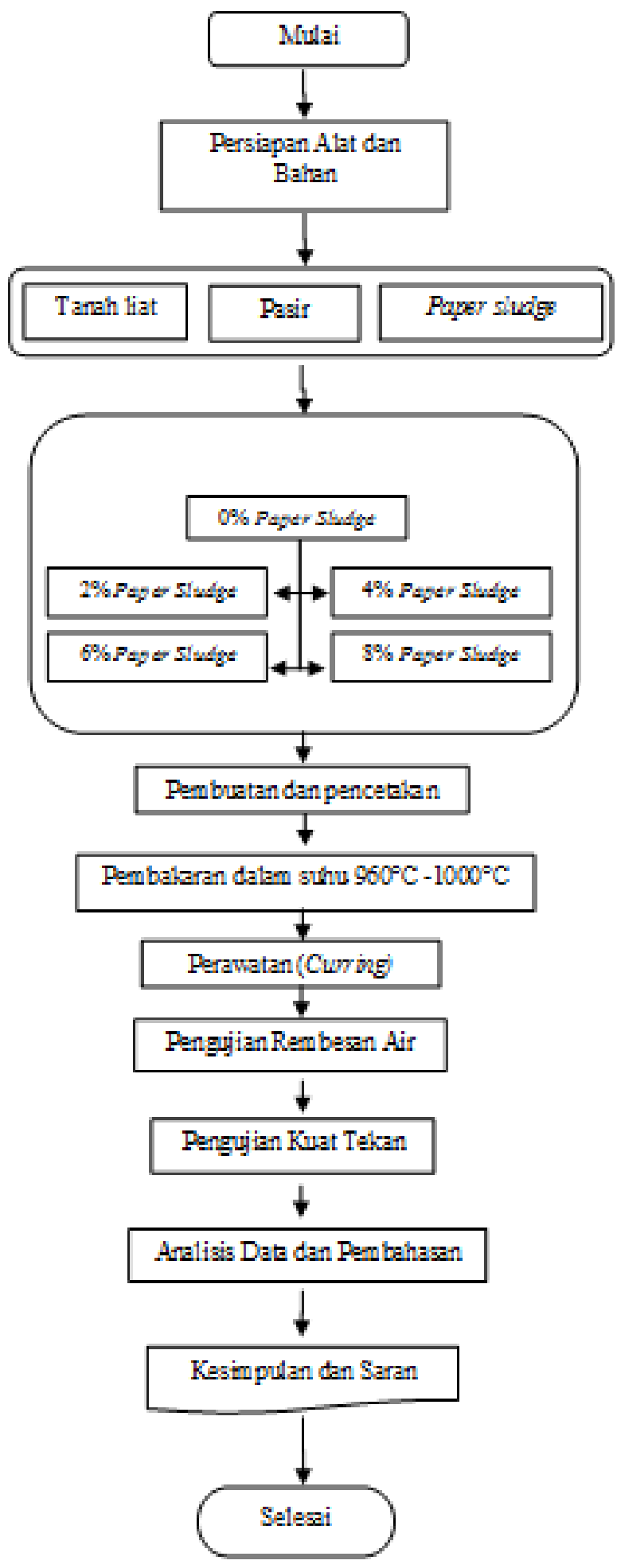

Gambar 1. Kerangka Pemikiran Penelitian 
Menurut SNI 03-4810-1998 Perawatan (curing) adalah tindakan untuk pemeriksaan proporsi campuran untuk kekuatan atau sebagai dasar untuk penerimaan atau pengendalian mutu. Perawatan (curing) pada ceiling brick yaitu dengan merendamnya ke dalam air hingga benar-benar jenuh air. Proses ini dilakukan 15 menit sebelum ceiling brick dirakit. Setelah dirakit perawatan pada ceiling brick yaitu menyiramnya dengan air guna menjaga kelembapan.

Pengujian berat volume dilakukan untuk memeriksa perbandingan volume ceiling brick tanpa penambahan paper sludge dengan ceiling brick yang dicampur paper sludge. Untuk mengetahui nilai berat volume dihitung menggunakan rumus seperti persamaan 1 dibawah ini.

$$
(D)=\frac{\text { BeratCeiling Brick }(W)}{\text { Volume Takaran }(V)} \times 100 \%
$$

Uji rembesan air pada ceiling brick sama seperti uji rembesan pada genteng dikarenakan mempunyai bahan dasar yang sama. Menurut Pratiwi dkk (2014), uji ketahanan perembesan air yang dilakukan berupa pengamatan yaitu pipa PVC 3/4" tinggi $6 \mathrm{~cm}$ yang sudah disediakan diletakan dipermukaan genteng dan permukaan luarnya direkatkan dengan lem agar air tidak bocor. Pipa diisi air setinggi $6 \mathrm{~cm}$ dan setelah itu hitung lama penyerapan air dalam pipa sampai air habis menggunakan stopwatch. Untuk mengetahui nilai penyerapan air dihitung menggunakan rumus seperti persamaan 2 dibawah ini.

Penyerapan air $(\mathrm{ml} /$ menit $)=\frac{\text { volume air }(\mathrm{ml})}{\text { waktu penyerapan air }(\text { menit })}$
Pengujian sifat mekanik ceiling brick yaitu uji kuat tekan yang mengacu pada SNI 03-6823-2002 tentang uji kuat tekan pada mortar semen portland. Nilai beban maksimum yang dicatat kemudian dihitung nilai kuat tekannya dengan rumus (SNI 1974:2011) seperti persamaan 3 dibawah ini.

$$
F c^{\prime}=P / A
$$

\section{Keterangan :}

$f_{c^{\prime}}=$ Kuat tekan $(M p a)$

$P=$ Beban tekan $(N)$

$A=$ Luas penampang benda uji $\left(\mathrm{mm}^{2}\right)$

Teknik pengumpulan data pada penelitian ini dilakukan dengan studi literatur penelitian terdahulu dan mencatat hasil pengujian yang telah dilakukan di laboratorium. Data penelitian berdasarkan data yang telah diperoleh dari hasil pengujian di laboratorium. Dari pengujian didapatkan data sebagai berikut:

1) Data primer

Data primer merupakan data yang di peroleh dari hasil pengamatan benda uji yang telah diuji di laboratorium. Data yang diperoleh berupa hasil dari nilai be rat volume, rembesan air, dan kuat tekan.

2) Data sekunder

Data sekunder merupakan data yang diper oleh dari studi literatur atau sumber yang su dah ada yang berhubungan dengan peneli tian ini.

Teknik pengolahan data menggunakan program Microsoft Excel dengan output grafik dan tabel sebagai penunjang analisa statistik deskriptif. Analisis statistik menggunakan Analisa Varian Satu Arah (ANOVA) dengan rumus lanjutan Rumus Tukey. Analisa akan dibantu menggunakan software SPSS Statistic 24. 
Adapun hipotesis dalam penelitian ini adalah sebagai berikut :

$\mathrm{H} 0$ = Ada perbedaan kuat tekan yang signifikan pada ceiling brick karena penambahan paper sludge yang bervariasi. $\mathrm{H} 1$ = Tidak ada perbedaan kuat tekan yang signifikan pada ceiling brick karena penambahan paper sludge yang bervariasi.

\section{HASIL}

\section{a.Hasil Pengujian Produk Ceiling Brick}

Pengujian pada produk ceiling brick ini bertujuan untuk mengetahui kualitas produk ceiling brick yang telah ditambahkan paper sludge dengan variasi $0 \%, 2 \%, 4 \%, 6 \%$, dan $8 \%$ dan untuk mengetahui berapa besar beban yang mampu ditahan oleh produk ceiling brick. Hasil dari pengujian produk ceiling brick dapat dilihat pada Tabel 1 dibawah ini.

Tabel 1. Hasil Pengujian Produk Ceiling

Brick

\begin{tabular}{cccc}
\hline $\begin{array}{c}\text { Kode } \\
\text { Benda Uji }\end{array}$ & $\begin{array}{c}\text { Nilai Rata- } \\
\text { rata Kuat } \\
\text { Tekan } \\
(\mathbf{M P a})\end{array}$ & $\begin{array}{c}\text { Nilai } \\
\text { Rata- rata } \\
\text { Penyera- } \\
\text { pan Air }\end{array}$ & $\begin{array}{c}\text { Nila Rata- } \\
\text { rata Berat } \\
\text { Volume }\end{array}$ \\
\cline { 2 - 4 }$\left(\mathbf{N} / \mathbf{m m}^{2}\right)$ & $(\mathbf{m l} / \mathbf{m e n i t})$ & $\left(\mathbf{g r} / \mathbf{c m}^{3}\right)$ \\
\hline $\mathrm{DK} 0$ & 8.43 & 0.35 & 1.79 \\
\hline $\mathrm{DK} 2$ & 9.39 & 0.37 & 1.69 \\
\hline $\mathrm{DK} 4$ & 11.28 & 0.35 & 1.66 \\
\hline $\mathrm{DK} 6$ & 10.31 & 0.42 & 1.66 \\
\hline $\mathrm{DK} 8$ & 8.3 & 0.36 & 1.64 \\
\hline
\end{tabular}

\section{b. Hasil Pengujian Morar Kubus Ceiling}

\section{Brick}

Pengujian pada mortar kubus ceiling brick ini bertujuan untuk mengetahui kualitas yang digunakan untuk ceiling brick yang telah ditambahkan paper sludge dengan variasi $0 \%$, $2 \%, 4 \%, 6 \%$, dan $8 \%$ dan untuk mengetahui berapa besar beban yang mampu ditahan oleh ceiling brick. Hasil dari pengujian produk ceiling brick dapat dilihat pada Tabel 2 berikut ini.
Tabel 2. Hasil Pengujian Mortar Kubus Ceiling Brick

\begin{tabular}{cccc}
\hline $\begin{array}{c}\text { Kode } \\
\text { Benda Uji }\end{array}$ & $\begin{array}{c}\text { Nilai Rata- } \\
\text { rata Kuat } \\
\text { Tekan } \\
(\mathbf{M P a})\end{array}$ & $\begin{array}{c}\text { Nila } \\
\text { Rata-rata } \\
\text { Penyera- } \\
\text { pan air }\end{array}$ & $\begin{array}{c}\text { Nilai Rata- } \\
\text { rata Berat } \\
\text { Volume }\end{array}$ \\
\cline { 2 - 4 } & $\begin{array}{ccc}\left(\mathbf{N} / \mathbf{m m}^{2}\right) \\
(\mathbf{m l} / \mathbf{m e n i t})\end{array}$ & $\left(\mathbf{g r} / \mathbf{c m}^{3}\right)$ \\
\hline M0 & 105.66 & 0.59 & 1.72 \\
\hline M2 & 112.67 & 0.54 & 1.68 \\
\hline M4 & 104.2 & 0.46 & 1.69 \\
\hline M6 & 98.55 & 0.27 & 1.67 \\
\hline M8 & 105.24 & 0.28 & 1.64 \\
\hline
\end{tabular}

\section{c. Hasil Uji Hipotesis Produk Ceiling Brick}

Uji hipotesis penelitian menggunakan analisis ANOVA One Way (analisis varian satu arah) kemudian dilakukan uji lanjut dengan rumus Tukey jika hasil yang didapatkan mengalami perbedaan.

Hasil uji hipotesis berat volume produk ceiling brick dapat dilihat pada Tabel 3 dan Tabel 4 sebagai berikut.

Tabel 3. Hasil Uji ANOVA Oneway Data Bebas dengan SPSS Statistics 24

\begin{tabular}{cccccc}
\hline \multicolumn{5}{c}{ ANOVA } \\
\hline \multicolumn{5}{c}{ Hasil Berat Volume Produk } \\
\hline $\begin{array}{c}\text { Sum of } \\
\text { Squares }\end{array}$ & df & $\begin{array}{c}\text { Mean } \\
\text { Square }\end{array}$ & F & Sig. \\
\hline $\begin{array}{c}\text { Between } \\
\text { Groups }\end{array}$ & 0.043 & 4 & 0.011 & 43.486 & 0 \\
\hline $\begin{array}{c}\text { Within } \\
\text { Groups }\end{array}$ & 0.002 & 10 & 0 & & \\
\hline Total & 0.045 & 14 & & & \\
\hline
\end{tabular}

Berdasarkan Tabel 3 sebelumnya uji ANOVA yang dilakukan terhadap berat volume produk ceiling brick dengan variasi paper sludge diperoleh Fhitung $>$ Ftabel, $43.486>$ 3,48 maka H0 ditolak sehingga hipotesis didukung oleh data, sehingga perlu uji lanjutan dengan uji posthoc Tukey. Hasil uji posthoc Tukey dapat dilihat pada Tabel 4 dibawah ini. 
Tabel 4. Hasil Pst Hoc Test Tukey

\begin{tabular}{|c|c|c|c|c|c|c|}
\hline \multicolumn{7}{|c|}{ Multiple Comparisons } \\
\hline \multicolumn{7}{|c|}{ Dependent Variable: Hasil Berat Volume } \\
\hline \multicolumn{7}{|c|}{ Tukey HSD } \\
\hline \multirow{2}{*}{$\begin{array}{l}\text { (I) Kode } \\
\text { BendaUJi }\end{array}$} & \multirow{2}{*}{$\begin{array}{l}\text { (J) Kode } \\
\text { Benda UJi }\end{array}$} & \multirow{2}{*}{$\begin{array}{c}\text { Mean Difference } \\
\text { (I-J) }\end{array}$} & \multirow{2}{*}{ Std. Error } & \multirow{2}{*}{ Sig. } & \multicolumn{2}{|c|}{ 95\% Confidence Interval } \\
\hline & & & & & Lower Bound & Upper Bound \\
\hline \multirow{4}{*}{ DK0 } & DK2 & $.09667 *$ & 0.01282 & 0 & 0.0545 & 0.1389 \\
\hline & DK4 & $.13000^{*}$ & 0.01282 & 0 & 0.0878 & 0.1722 \\
\hline & DK6 & $.13000^{*}$ & 0.01282 & 0 & 0.0878 & 0.1722 \\
\hline & DK8 & $.15000^{*}$ & 0.01282 & 0 & 0.1078 & 0.1922 \\
\hline \multirow{4}{*}{ DK2 } & DK0 & $-.09667 *$ & 0.01282 & 0 & -0.1389 & -0.0545 \\
\hline & DK4 & 0.03333 & 0.01282 & 0.144 & -0.0089 & 0.0755 \\
\hline & DK6 & 0.03333 & 0.01282 & 0.144 & -0.0089 & 0.0755 \\
\hline & DK8 & $.05333 *$ & 0.01282 & 0.013 & 0.0111 & 0.0955 \\
\hline \multirow{4}{*}{ DK4 } & DK0 & $-.13000^{*}$ & 0.01282 & 0 & -0.1722 & -0.0878 \\
\hline & DK2 & -0.03333 & 0.01282 & 0.144 & -0.0755 & 0.0089 \\
\hline & DK6 & 0 & 0.01282 & 1 & -0.0422 & 0.0422 \\
\hline & DK8 & 0.02 & 0.01282 & 0.551 & -0.0222 & 0.0622 \\
\hline \multirow{4}{*}{ DK6 } & DK0 & $-.13000 *$ & 0.01282 & 0 & -0.1722 & -0.0878 \\
\hline & DK2 & -0.03333 & 0.01282 & 0.144 & -0.0755 & 0.0089 \\
\hline & DK4 & 0 & 0.01282 & 1 & -0.0422 & 0.0422 \\
\hline & DK8 & 0.02 & 0.01282 & 0.551 & -0.0222 & 0.0622 \\
\hline \multirow{4}{*}{ DK8 } & DK0 & $-.15000^{*}$ & 0.01282 & 0 & -0.1922 & -0.1078 \\
\hline & DK2 & $-.05333^{*}$ & 0.01282 & 0.013 & -0.0955 & -0.0111 \\
\hline & DK4 & -0.02 & 0.01282 & 0.551 & -0.0622 & 0.0222 \\
\hline & DK6 & -0.02 & 0.01282 & 0.551 & -0.0622 & 0.0222 \\
\hline
\end{tabular}

Dari Tabel 4 di atas dapat disimpulkan bahwa terdapat perbedaan berat volume secara signifikan dikarenakan terdapat nilai sig $<0,05$.

Hasil uji hipotesis rembesan air produk ceiling brick yang telah di campur paper sludge dapat dilihat pada Tabel 5 berikut ini.

Tabel 5. Hasil Uji ANOVA Oneway Data Bebas dengan SPSS Statistics 24

\begin{tabular}{|c|c|c|c|c|c|}
\hline \multicolumn{6}{|c|}{ ANOVA } \\
\hline \multicolumn{6}{|c|}{ Hasil Uji Rembesan Produk } \\
\hline & $\begin{array}{c}\text { Sum of } \\
\text { Squares }\end{array}$ & df & $\begin{array}{c}\text { Mean } \\
\text { Square }\end{array}$ & $\mathbf{F}$ & Sig. \\
\hline $\begin{array}{l}\text { Between } \\
\text { Groups }\end{array}$ & 0.01 & 4 & 0.003 & 1.007 & 0.449 \\
\hline $\begin{array}{l}\text { Within } \\
\text { Groups }\end{array}$ & 0.025 & 10 & 0.003 & & \\
\hline Total & 0.035 & 14 & & & \\
\hline
\end{tabular}

Berdasarkan Tabel 5 di atas uji ANOVA yang dilakukan terhadap rembesan air produk ceiling brick dengan variasi paper sludge diperoleh hasil Fhitung $=1.007$, df3 $=4$, df4 $=10$. Fhitung dari ouput adalah 1.007 sedangkan Ftabel 3.48. Dari Tabel 4.10 terlihat bahwa Fhitung $<$ Ftabel, $1.007<3,48$ maka H0 diterima. Karena hasil dari uji ANOVA produk ceiling brick dengan penambahan variasi paper sludge tidak ada perbedaan nilai rembesan air yang signifikan maka tidak perlu diuji lanjut dengan rumus Tukey. Hasil uji hipotesis kuat tekan produk ceiling brick yang telah di campur paper sludge dapat dilihat pada Tabel 6 sebagai berikut: 
Tabel 6. Hasil Uji ANOVA Oneway Data Bebas dengan SPSS Statistics 24

\begin{tabular}{llllll}
\hline \multicolumn{6}{c}{ ANOVA } \\
\hline \multicolumn{7}{c}{ Hasil Uji Kuat Tekan Produk } & & \\
\hline & $\begin{array}{l}\text { Sum of } \\
\text { Squares }\end{array}$ & df & $\begin{array}{l}\text { Mean } \\
\text { Square }\end{array}$ & F & Sig. \\
\hline $\begin{array}{l}\text { Between } \\
\text { Groups }\end{array}$ & 21.14 & 4 & 5.285 & 3.688 & 0.043 \\
\hline $\begin{array}{l}\text { Within } \\
\text { Groups }\end{array}$ & 14.331 & 10 & 1.433 & & \\
\hline Total & 35.471 & 14 & & & \\
\hline
\end{tabular}

Berdasarkan Tabel 6 di atas uji ANOVA yang dilakukan terhadap kuat tekan produk ceiling brick dengan variasi paper sludge diperoleh hasil Fhitung $=3.688$, df3 $=4$, df4 $=10$. Pengambilan keputusan berdasar perbandingan Fhitung dengan Ftabel yaitu jika
Fhitung $>$ Ftabel maka H0 ditolak, Fhitung $<$ Ftabel maka H0 diterima. Fhitung dari ouput adalah 3.688 sedangkan Ftabel 3.48. Dari Tabel 4.8 terlihat bahwa Fhitung $>$ Ftabel, $3.688>$ 3,48 maka H0 ditolak sehingga hipotesis didukung oleh data, sehingga perlu uji lanjutan dengan uji posthoc Tukey. Hasil uji posthoc Tukey dapat dilihat pada Tabel 7 di bawah ini.

Dari Tabel 7 dapat dilihat bahwa semua data kelompok nilai sig. $>0.05$. kesimpulan dari kelima variasi tersebut mengalami perbedaan, tetapi bila dilihat dari angka Sig. dan mean difference produk ceiling brick mengalami perbedaan meskipun tidak signifikan. Produk ceiling brick dengan variasi paper sludge 4\% atau DK4 memiliki kuat tekan tertinggi bila dibandingkan dengan varian lainnya.

Tabel 7. Hasil Pst Hoc Test Tukey

\begin{tabular}{|c|c|c|c|c|c|c|}
\hline \multicolumn{7}{|c|}{ Multiple Comparisons } \\
\hline \multicolumn{7}{|c|}{ Dependent Variable: Hasil Uji Kuat Tekan Produk } \\
\hline \multicolumn{7}{|c|}{ Tukey HSD } \\
\hline \multirow{2}{*}{$\begin{array}{l}\text { (I) Jenis } \\
\text { Benda Uji }\end{array}$} & \multirow{2}{*}{$\begin{array}{l}\text { (J) Jenis } \\
\text { Benda Uji }\end{array}$} & \multirow{2}{*}{$\begin{array}{c}\text { Mean Difference } \\
\text { (I-J) }\end{array}$} & \multirow{2}{*}{ Std. Error } & \multirow{2}{*}{ Sig. } & \multicolumn{2}{|c|}{ 95\% Confidence Interval } \\
\hline & & & & & Lower Bound & Upper Bound \\
\hline \multirow{4}{*}{ DK0 } & Dk2 & -0.96 & 0.977 & 0.857 & -4.18 & 2.26 \\
\hline & DK4 & -3.023 & 0.977 & 0.068 & -6.24 & 0.19 \\
\hline & DK6 & -1.873 & 0.977 & 0.368 & -5.09 & 1.34 \\
\hline & DK8 & 0.137 & 0.977 & 1 & -3.08 & 3.35 \\
\hline \multirow{4}{*}{ Dk2 } & DK0 & 0.96 & 0.977 & 0.857 & -2.26 & 4.18 \\
\hline & DK4 & -2.063 & 0.977 & 0.287 & -5.28 & 1.15 \\
\hline & DK6 & -0.913 & 0.977 & 0.877 & -4.13 & 2.3 \\
\hline & DK8 & 1.097 & 0.977 & 0.792 & -2.12 & 4.31 \\
\hline \multirow{4}{*}{ DK4 } & DK0 & 3.023 & 0.977 & 0.068 & -0.19 & 6.24 \\
\hline & Dk2 & 2.063 & 0.977 & 0.287 & -1.15 & 5.28 \\
\hline & DK6 & 1.15 & 0.977 & 0.764 & -2.07 & 4.37 \\
\hline & DK8 & 3.16 & 0.977 & 0.055 & -0.06 & 6.38 \\
\hline \multirow{4}{*}{ DK6 } & DK0 & 1.873 & 0.977 & 0.368 & -1.34 & 5.09 \\
\hline & Dk2 & 0.913 & 0.977 & 0.877 & -2.3 & 4.13 \\
\hline & DK4 & -1.15 & 0.977 & 0.764 & -4.37 & 2.07 \\
\hline & DK8 & 2.01 & 0.977 & 0.308 & -1.21 & 5.23 \\
\hline \multirow{4}{*}{ DK8 } & DK0 & -0.137 & 0.977 & 1 & -3.35 & 3.08 \\
\hline & $\mathrm{Dk} 2$ & -1.097 & 0.977 & 0.792 & -4.31 & 2.12 \\
\hline & DK4 & -3.16 & 0.977 & 0.055 & -6.38 & 0.06 \\
\hline & DK6 & -2.01 & 0.977 & 0.308 & -5.23 & 1.21 \\
\hline
\end{tabular}




\section{d. Hasil Uji Hipotesis Mortar Kubus Ceil-} ing Brick

Pengolahan data dalam penelitian ini menggunakan analisis ANOVA One Way (analisis varian satu arah) yaitu uji perbedaan rerata lebih dari dua kelompok pada satu arah menggunakan program SPSS dan uji selanjutnya yang akan dilakukan adalah uji posthoc test untuk mengetahui nilai optimum kuat tekan dan rembesan air mortar kubus ceiling brick pada campuran paper sludge keberapa. Penentuan kesimpulan menggunakan rumus Tukey akan dilakukan dengan membandingkan harga F hitung dan F tabel. Hipotesis dalam penelitian ini untuk mengetahui adanya perbedaan kuat tekan celing brick yang signifikan. Hasil uji hipotesis berat volume mortar kubus ceiling yang telah dicampur paper sludge dapat dilihat pada Tabel 8 di bawah ini.

\begin{tabular}{|c|c|c|c|c|c|}
\hline & & INO & & & \\
\hline Berat Vol & me Mortar 1 & ubus & & & \\
\hline & $\begin{array}{l}\text { Sum of } \\
\text { Squares }\end{array}$ & df & $\begin{array}{l}\text { Mean } \\
\text { Square }\end{array}$ & $\mathbf{F}$ & Sig. \\
\hline $\begin{array}{l}\text { Between } \\
\text { Groups }\end{array}$ & 0.014 & 4 & 0.004 & 0.487 & 0.745 \\
\hline $\begin{array}{l}\text { Within } \\
\text { Groups }\end{array}$ & 0.147 & 20 & 0.007 & & \\
\hline Total & 0.161 & 24 & & & \\
\hline
\end{tabular}

Berdasarkan Tabel 8 di atas uji ANOVA yang dilakukan terhadap berat volume mortar kubus ceiling brick dengan variasi paper sludge diperoleh hasil Fhitung $=0.487$, df3 $=4$, df $4=20$. Pengambilan keputusan berdasar perbandingan Fhitung dengan Ftabel yaitu jika Fhitung > Ftabel maka H0 ditolak, Fhitung $<$ Ftabel maka H0 diterima. Fhitung dari ouput adalah 0.487 sedangkan Ftabel 2.87. Dari Tabel 8 terlihat bahwa Fhitung<
Ftabel, $0.487<2.87$ maka H0 diterima sehingga hipotesis tidak didukung oleh data, hal ini dapat disimpulkan bahwa nilai mean ada perbedaan nilai berat volume tapi tidak signifikan. Karena hasil dari uji ANOVA mortar kubus ceiling brick dengan penambahan variasi paper sludge tidak ada perbedaan nilai berat volume yang signifikan maka tidak perlu diuji lanjut dengan rumus Tukey.

Hasil uji hipotesis rembesan air mortar kubus ceiling brick dapat dilihat pada Tabel 9 dan Tabel 10 sebagai berikut:

\section{Tabel 9. Hasil Uji ANOVA Oneway Data Bebas dengan SPSS}

\begin{tabular}{llllll}
\hline \multicolumn{5}{c}{ ANOVA } \\
\hline Hasil Uji Rembesan Air Mortar \\
\hline $\begin{array}{l}\text { Sum of } \\
\text { Squares }\end{array}$ & df & $\begin{array}{c}\text { Mean } \\
\text { Square }\end{array}$ & F & Sig. \\
\hline $\begin{array}{l}\text { Between } \\
\text { Groups }\end{array}$ & 0.432 & 4 & 0.108 & 6.212 & 0.002 \\
\hline $\begin{array}{l}\text { Within } \\
\text { Groups }\end{array}$ & 0.348 & 20 & 0.017 & & \\
\hline Total & 0.78 & 24 & & \\
\hline
\end{tabular}

Dari Tabel 9 di atas uji ANOVA yang dilakukan terhadap rembesan air mortar kubus ceiling brick dengan variasi paper sludge diperoleh hasil Fhitung $=6.212$, df3 $=4, \mathrm{df} 4=20$. Pengambilan keputusan berdasar perbandingan Fhitung dengan Ftabel yaitu jika Fhitung> Ftabel maka H0 ditolak, Fhitung $<$ Ftabel maka H0 diterima. Fhitung dari ouput adalah 6.212 sedangkan Ftabel 2.87. Berdasarkan Tabel 9 dapat dilihat bahwa Fhitung $>$ Ftabel, 6.212 > 2.87 maka H0 ditolak sehingga hipotesis didukung oleh data, sehingga perlu uji lanjutan dengan uji posthoc Tukey. Hasil uji posthoc tukey dapat dilihat pada Tabel 10 berikut ini. 
Tabel 10. Hasil Pst Hoc Test Tukey

\section{Multiple Comparisons}

\begin{tabular}{|c|c|c|c|c|c|c|}
\hline \multicolumn{7}{|c|}{ Dependent Variable: Hasil Uji Rembesan Air Mortar } \\
\hline \multirow{3}{*}{$\begin{array}{l}\text { (I) Benda } \\
\text { Uji Mortar }\end{array}$} & \multirow{3}{*}{$\begin{array}{l}\text { (J) Benda } \\
\text { Uji Mortar }\end{array}$} & \multirow{3}{*}{$\begin{array}{c}\text { Mean Difference } \\
\text { (I-J) }\end{array}$} & \multirow{3}{*}{ Std. Error } & \multirow{3}{*}{ Sig. } & & \\
\hline & & & & & \multicolumn{2}{|c|}{ 95\% Confidence Interval } \\
\hline & & & & & Lower Bound & Upper Bound \\
\hline \multirow{4}{*}{ M0 } & M2 & 0.046 & 0.08342 & 0.98 & -0.2036 & 0.2956 \\
\hline & M4 & 0.128 & 0.08342 & 0.553 & -0.1216 & 0.3776 \\
\hline & M6 & $.31600^{*}$ & 0.08342 & 0.009 & 0.0664 & 0.5656 \\
\hline & M8 & $.31000^{*}$ & 0.08342 & 0.011 & 0.0604 & 0.5596 \\
\hline \multirow{4}{*}{ M2 } & M0 & -0.046 & 0.08342 & 0.98 & -0.2956 & 0.2036 \\
\hline & M4 & 0.082 & 0.08342 & 0.86 & -0.1676 & 0.3316 \\
\hline & M6 & $.27000^{*}$ & 0.08342 & 0.03 & 0.0204 & 0.5196 \\
\hline & M8 & $.26400^{*}$ & 0.08342 & 0.035 & 0.0144 & 0.5136 \\
\hline \multirow{4}{*}{ M4 } & M0 & -0.128 & 0.08342 & 0.553 & -0.3776 & 0.1216 \\
\hline & M2 & -0.082 & 0.08342 & 0.86 & -0.3316 & 0.1676 \\
\hline & M6 & 0.188 & 0.08342 & 0.201 & -0.0616 & 0.4376 \\
\hline & M8 & 0.182 & 0.08342 & 0.227 & -0.0676 & 0.4316 \\
\hline \multirow{4}{*}{ M6 } & M0 & $-.31600 *$ & 0.08342 & 0.009 & -0.5656 & -0.0664 \\
\hline & M2 & $-.27000 *$ & 0.08342 & 0.03 & -0.5196 & -0.0204 \\
\hline & M4 & -0.188 & 0.08342 & 0.201 & -0.4376 & 0.0616 \\
\hline & M8 & -0.006 & 0.08342 & 1 & -0.2556 & 0.2436 \\
\hline \multirow{4}{*}{ M8 } & M0 & $-.31000 *$ & 0.08342 & 0.011 & -0.5596 & -0.0604 \\
\hline & M2 & $-.26400 *$ & 0.08342 & 0.035 & -0.5136 & -0.0144 \\
\hline & M4 & -0.182 & 0.08342 & 0.227 & -0.4316 & 0.0676 \\
\hline & M6 & 0.006 & 0.08342 & 1 & -0.2436 & 0.2556 \\
\hline
\end{tabular}

*. The mean difference is significant at the 0.05 level.

Dari Tabel 10 di atas dapat disimpulkan bahwa terdapat perbedaan nilai rembesan air secara signifikan. Mortar kubus yang memiliki perbedaan secara signifikan adalah MT0 dengan MT6, MT0 dengan MT8, MT2 dengan MT6, dan MT2 dengan MT8. MT0 dan MT2 memiliki nilai lebih tinggi dari MT6 dan MT8. Pada uji rembesan air yang memiliki nilai rembesan rendah berarti memiliki rembesan air yang baik.

Hasil uji hjipotesis kuat tekan mortar kubus ceiling brick dapat dilihat pada Tabel 11 dibawah ini.
Tabel 11. Hasil Uji ANOVA Oneway Data Bebas dengan SPSS Statistics 24

\section{ANOVA}

Hasil Kuat Tekan Mortar Kubus

\begin{tabular}{lccccc}
\hline & $\begin{array}{c}\text { Sum of } \\
\text { Squares }\end{array}$ & df & $\begin{array}{c}\text { Mean } \\
\text { Square }\end{array}$ & F & Sig. \\
\hline $\begin{array}{l}\text { Between } \\
\text { Groups }\end{array}$ & 506.137 & 4 & 126.534 & 0.21 & 0.93 \\
\hline $\begin{array}{l}\text { Within } \\
\text { Groups }\end{array}$ & 12032.282 & 20 & 601.614 & & \\
\hline Total & 12538.418 & 24 & & & \\
\hline
\end{tabular}

Berdasarkan Tabel 11 di atas uji ANOVA yang dilakukan terhadap kuat tekan mortar kubus ceiling brick dengan variasi paper sludge diperoleh hasil Fhitung $=0.210$, df3 $=$ 4, df4 =20. Dari Tabel 11 terlihat bahwa Fhi- 
tung $<$ Ftabel, $0.210<2.87$ maka H0 diterima sehingga dapat disimpulkan bahwa nilai mean ada perbedaan nilai kuat tekan tapi tidak signifikan. Karena hasil dari uji ANOVA mortar kubus ceiling brick dengan penambahan variasi paper sludge tidak ada perbedaan nilai kuat tekan yang signifikan maka tidak perlu diuji lanjut dengan rumus Tukey.

\section{e. Campuran Paper Sludge yang Meng- hasilkan Kuat Tekan Optimum}

Uji kuat tekan pada penelitian ini dilakukan pada dua jenis benda uji yaitu benda uji berbentuk produk ceiling brick untuk mengetahui kualitas produk ceiling brick dari pabrik tersebut dan benda uji berbentuk mortar atau kubus dengan ukuran $5 \mathrm{~cm}$ x $5 \mathrm{~cm}$ x $5 \mathrm{~cm}$. Hasil kuat tekan dapat dilihat pada Tabel 12 sebagai berikut.

Tabel 12. Ringkasan Hasil Uji Kuat Tekan Produk dan Mortar Kubus Ceiling Brick

\begin{tabular}{ccc}
\hline \multirow{2}{*}{ Variasi } & \multicolumn{2}{c}{ Uji Kuat Tekan } \\
\cline { 2 - 3 } & $\begin{array}{c}\text { Produk Ceiling } \\
\text { Brick }\end{array}$ & $\begin{array}{c}\text { Mortar Kubus Ceil- } \\
\text { ing Brick }\end{array}$ \\
\cline { 2 - 3 } (Mpa) & (Mpa) \\
\hline $0 \%$ & 8.43 & 105.66 \\
\hline $2 \%$ & 9.39 & 112.67 \\
\hline $4 \%$ & 11.28 & 104.2 \\
\hline $6 \%$ & 10.31 & 98.55 \\
\hline $8 \%$ & 8.3 & 105.24 \\
\hline
\end{tabular}

\section{PEMBAHASAN}

\section{a. Hasil Pengujian Produk Ceiling Brick}

Dari hasil Tabel 1 sebelumnya menunjukkan hasil pengujian kuat tekan produk ceiling brick dengan campuran paper sludge yaitu $0 \%$ sebesar $8.43 \mathrm{MPa}, 2 \%$ sebesar 9.39 $\mathrm{MPa}, 4 \%$ sebesar $11.28 \mathrm{MPa}$, 6\% sebesar $10.31 \mathrm{MPa}$, dan $8 \%$ sebesar $8.30 \mathrm{MPa}$. Hasil pengujian rembesan air pada produk ceiling brick yang telah di campur paper sludge dengan variasi $0 \%$ sebesar $0.35 \mathrm{ml} / \mathrm{menit}$, $2 \%$ sebesar $0.37 \mathrm{ml} /$ menit, $4 \%$ sebesar $0.35 \mathrm{ml} /$ menit, $6 \%$ sebesar $0.42 \mathrm{ml} / \mathrm{menit}$, dan $8 \%$ sebesar $0.36 \mathrm{ml} /$ menit. Pada pengujian ini, semakin rendah nilai rembesan air semakin baik kualitas produk ceiling brick dalam ketahanan air. Dan hasil pengujian berat volume produk ceiling brick ratarata dengan variasi campuran paper sludge 0\% sebesar $1.79 \mathrm{gr} / \mathrm{cm} 3,2 \%$ sebesar $1.69 \mathrm{gr} /$ $\mathrm{cm} 3,4 \%$ sebesar $1.66 \mathrm{gr} / \mathrm{cm} 3,6 \%$ sebesar $1.66 \mathrm{gr} / \mathrm{cm} 3$, dan $8 \%$ sebesar $1.64 \mathrm{gr} / \mathrm{cm} 3$.

\section{b. Hasil Pengujian Mortar Kubus Ceiling Brick}

Berdasarkan Tabel 2 sebelumnya menunjukkan hasil pengujian kuat tekan mortar kubus ceiling brick dengan campuran paper sludge yaitu $0 \%$ sebesar $105.66 \mathrm{MPa}$, $2 \%$ sebesar $112.67 \mathrm{MPa}, 4 \%$ sebesar 104.20 $\mathrm{MPa}, 6 \%$ sebesar $98.55 \mathrm{MPa}$, dan $8 \%$ sebesar $105.24 \mathrm{MPa}$. Hasil pengujian rembesan air pada mortar kubus ceiling brick yang telah dicampur paper sludge dengan nilai rata-rata variasi $0 \%$ sebesar $0,59 \mathrm{ml} /$ menit, $2 \%$ sebesar $0,54 \mathrm{ml} /$ menit, $4 \%$ sebesar 0,46 $\mathrm{ml} / \mathrm{menit}$, $6 \%$ sebesar $0,27 \mathrm{ml} / \mathrm{menit}$, dan $8 \%$ sebesar $0,28 \mathrm{ml} / \mathrm{menit}$. Dan hasil pengujian berat volume mortar ceiling brick rata-rata dengan variasi campuran paper sludge $0 \%$ sebesar $1.72 \mathrm{gr} / \mathrm{cm} 3,2 \%$ sebesar $1.68 \mathrm{gr} /$ $\mathrm{cm} 3,4 \%$ sebesar $1.69 \mathrm{gr} / \mathrm{cm} 3,6 \%$ sebesar $1.67 \mathrm{gr} / \mathrm{cm} 3$, dan $8 \%$ sebesar $1.64 \mathrm{gr} / \mathrm{cm} 3$.

\section{c. Hasil Uji Hipotesi Produk Ceiling Brick}

Berdasarkan uji hipotesis kuat tekan produk ceiling brick yang tertera pada Tabel 6 dan Tabel 7 sebelumnya menunjukkan perbedaan kuat tekan produk ceiling brick yang di campur paper sludge tetapi tidak signifikan. Hasil tersebut diperoleh dari analisis data dimana Fhitung $>$ Ftabel, 3.688 
$>$ 3,48 maka H0 ditolak dan perlu uji lanjutan dengan uji posthoc Tukey. Dan dari hasil uji posthoc Tukey dapat dilihat bahwa semua data kelompok nilai sig. $>0.05$. Kesimpulan dari kelima variasi tersebut mengalami perbedaan, tetapi bila dilihat dari angka Sig. dan mean difference produk ceiling brick mengalami perbedaan meskipun tidak signifikan.

Hasil uji hipotesis rembesan air terhadap produk ceiling brick terdapat perbedaan. Dan dari hasil analisis data dimana Fhitung $<$ Ftabel, $1.007<3$,48 maka H0 diterima sehingga hipotesis tidak didukung oleh data, hal ini dapat disimpulkan bahwa produk ceiling brick dengan penambahan variasi paper sludge tidak ada perbedaan nilai rembesan air yang signifikan. Uji hipotesis berat volume menggunakan SPSS Statistic 24 menunjukkan bahwa Fhitung $>$ Ftabel, $43.486>3,48$ maka $\mathrm{H} 0$ ditolak sehingga hipotesis didukung oleh data, sehingga perlu uji lanjutan dengan uji posthoc Tukey. Dari hasil uji posthoc Tukey dapat disimpulkan bahwa terdapat perbedaan berat volume secara signifikan antara lain adalah variasi $0 \%$ dengan variasi $2 \%$, variasi $0 \%$ dengan variasi $4 \%$, variasi $0 \%$ dengan variasi $6 \%$, dan variasi $0 \%$ dengan variasi $8 \%$. Sedangkan pada variasi $4 \%$ dengan variasi $6 \%$ tidak mengalami perbedaan.

\section{d. Hasil Uji Hipotesi Produk Ceiling Brick}

Uji hipotesis kuat tekan mortar kubus ceiling brick menunjukkan bahwa terdapat perbedaan kuat tekan mortar kubus ceiling brick yang di campur paper sludge. Hasil tersebut diperoleh dari analisis data dimana Fhitung < Ftabel, $0.210<2.87$ maka H0 diterima sehingga hipotesis tidak didukung oleh data, hal ini dapat disimpulkan bahwa nilai mean ada perbedaan nilai kuat tekan tetapi tidak signifikan.
Uji hipotesis rembesan air mortar kubus ceiling brick dihasilkan analisis data dimana Fhitung > Ftabel, $6.212>2.87$ maka H0 ditolak sehingga hipotesis didukung oleh data, sehingga perlu uji lanjutan dengan uji posthoc Tukey. Hasil dari uji posthoc Tukey disimpulkan bahwa terdapat perbedaan nilai rembesan air secara signifikan. Mortar kubus ceiling brick memiliki perbedaan secara signifikan adalah variasi $0 \%$ dengan variasi $6 \%$, variasi $0 \%$ dengan variasi $8 \%$, variari $2 \%$ dengan variasi $6 \%$, variari $2 \%$ dengan variasi $8 \%$.

Dari hasil uji hipotesis penelitian menggunakan SPSS Satistic 24 menunjukkan bahwa Fhitung $<$ Ftabel, $0.487<2.87$ maka H0 diterima sehingga hipotesis tidak didukung oleh data, hal ini dapat disimpulkan bahwa mortar kubus ceiling brick dengan penambahan variasi paper sludge tidak ada perbedaan nilai berat volume yang signifikan.

\section{e. Campuran Paper Sludge yang Meng- hasilkan Kuat Tekan Optimum}

Berdasarkan hasil pengujian pada Tabel 12 sebelumnya nilai kuat tekan tertinggi pada produk ceiling brick terdapat pada campuran paper sludge 4\% dengan kuat tekan 11.28 $\mathrm{MPa}$ dan campuran paper sludge pada mortar kubus ceiling brick yang menghasilkan kuat tekan optimum terdapat pada campuran variasi 2\% dengan kuat tekan $112.67 \mathrm{MPa}$.

\section{SIMPULAN}

Dari hasil penelitian ini, pengujian sifat mekanik terhadap produk ceiling brick yang telah dicampur paper sludge yaitu mengenai uji kuat tekan. Sehingga diperoleh hasil ratarata uji kuat tekan dengan variasi berurut-urut $0 \%, 2 \%, 4 \%, 6 \%$, dan $8 \%$ sebesar $8.43 \mathrm{MPa}$, 9.39 $\mathrm{MPa}, 11.28 \mathrm{MPa}, 10.31 \mathrm{MPa}$, dan 8.30 
MPa. Sedangkan pengujian sifat fisik pada produk ceiling brick yang telah dicampur paper sludge yaitu meliputi uji rembesan air dan berat volume. Adapun hasil pengujian rembesan air produk ceiling brick dengan campuran paper sludge variasi $0 \%$ sebesar $0.35 \mathrm{ml} / \mathrm{me}$ nit, 2\% sebesar $0.37 \mathrm{ml} / \mathrm{menit}$, $4 \%$ sebesar $0.35 \mathrm{ml} / \mathrm{menit}, 6 \%$ sebesar $0.42 \mathrm{ml} / \mathrm{menit}$, dan $8 \%$ sebesar $0.36 \mathrm{ml} /$ menit. Dan hasil pengujian rata-rata berat volume produk ceiling brick dengan variasi campuran paper sludge $0 \%$ sebesar $1.79 \mathrm{gr} / \mathrm{cm} 3,2 \%$ sebesar $1.69 \mathrm{gr} / \mathrm{cm} 3$, $4 \%$ sebesar $1.66 \mathrm{gr} / \mathrm{cm} 3,6 \%$ sebesar $1.66 \mathrm{gr} /$ $\mathrm{cm} 3$, dan $8 \%$ sebesar $1.64 \mathrm{gr} / \mathrm{cm} 3$. Pengujian sifat mekanik terhadap mortar kubus ceiling brick yaitu mengenai uji kuat tekan. Nilai rata-rata kuat tekan mortar ceiling brick dengan campuran paper sludge yang bervariasi berurut-urut $0 \%, 2 \%, 4 \%, 6 \%$, dan $8 \%$ sebesar 105.66 MPa, 112.67 MPa, 104.20 MPa, 98.55 MPa, dan 105.24 MPa. Sedangkan pengujian sifat fisik pada mortar kubus ceiling meliputi uji rembesan air dan berat volume. Adapun hasil nilai rata-rata rembesan air pada mortar kubus ceiling brick yang dicampur dengan paper sludge dengan variasi $0 \%$ sebesar $0,59 \mathrm{ml} /$ menit, $2 \%$ sebesar $0,54 \mathrm{ml} / \mathrm{menit}, 4 \%$ sebesar $0,46 \mathrm{ml} / \mathrm{menit}$, $6 \%$ sebesar $0,27 \mathrm{ml} / \mathrm{menit}$, dan $8 \%$ sebesar $0,28 \mathrm{ml} / \mathrm{menit}$. Dan hasil pengujian rata-rata berat volume mortar kubus ceiling brick dengan variasi campuran paper sludge $0 \%$ sebesar $1.72 \mathrm{gr} / \mathrm{cm} 3,2 \%$ sebesar $1.68 \mathrm{gr} /$ $\mathrm{cm} 3,4 \%$ sebesar $1.69 \mathrm{gr} / \mathrm{cm} 3,6 \%$ sebesar $1.67 \mathrm{gr} / \mathrm{cm} 3$, dan $8 \%$ sebesar $1.64 \mathrm{gr} / \mathrm{cm} 3$.

Dari penelitian ini, uji kuat tekan dan rembesan air terhadap produk ceiling brick yang telah dicampur paper sludge mengalami perbedaan tetapi tidak signifikan. Sedangkan uji berat volume tehadap produk ceiling brick yang telah dicampur paper sludge mengalami perbedaan yang signifikan. Uji kuat tekan dan berat volume terhadap mortar kubus ceiling brick yang telah dicampur paper sludge mengalami perbedaan tetapi tidak signifikan. Sedangkan uji rembesan air tehadap mortar kubus ceiling brick yang telah dicampur paper sludge mengalami perbedaan yang signifikan. Campuran paper sludge $4 \%$ pada produk ceiling brick dan campuran paper sludge 2\% pada mortar kubus ceiling brick menghasilkan kuat tekan optimum.

\section{DAFTAR RUJUKAN}

Anonim. 2004. Pengkajian Pemanfaatan Ba han Sisa untuk Land Application di Ar eal Lahan Hutan Tanaman Industri (HTI) PT. RAPP. Kerjasama PT. RAPP dengan Balai Besar Pulp danKertas (BBPK). Hardiani, H. dan S. Sugesty. 2009. Peman faatan Limbah Sludge Industri Kertas Siga ret untuk Bahan Baku Bata Beton. Berita Selulosa. Vol. 44 No.2.

Hastutik, W., Aprianto, H. B. Nasution. 2006. Pengaruh Limbah Padat Pabrik Kertas terh adap Hasil Tanaman Bawang Merah. Fakultas Pertanian. Universitas Tunas Pembangunan.

Irawan, Bambang. 2006, "Handout penjelasan tentang mekanisma produksi kertas", Gresik : PT. Adiprima Suraprinta Khusna, Himnil. 2012. Analisis Kandungan Kimia Dan Pemanfaatan Sludge Indus tri Kertas Sebagai Bahan Pembuatan Bata ko. FMIPA Universitas Negeri Semarang 
Maghfironi, Adzim. 2011. Dak Beton Keraton (online), (http://dakbetonkeraton.blogspot. com), diakses 18 Januari 2018 Sihombing, Brelian (2009), Pembuatan Dan Karakterisasi Batako Ringanyang Dibuat Dari Sludge (Limbah Padat) Industri Ker tas - Semen. Tesis. Univrsitas Sumatera
Utara, Medan

SNI 03-6823-2002 Uji Kuat Tekan Mortar Se men Portland Untuk Pekerjaan Sipil: Badan Standar Nasional

SNI 1974:2011. Cara uji kuat tekan beton den gan benda uji silinder. Badan Standar $\mathrm{Na}$ sional 
54 JURNAL BANGUNAN, VOL. 25, NO.1, MARET 2020: 41-54 